\title{
Uji Aktivitas Antibakteri Ekstrak Terpurifikasi Daun Mangga Arumanis (Mangifera indica L.) dan Identifikasi Flavonoid dengan KLT
}

\section{(Antibacterial Activity of Arumanis Mango Leaves (Mangifera indica L.) Purified Extract and Identification of Flavonoid by TLC)}

\author{
E-mail: andini@unwahas.ac.id \\ Article Info: \\ Received: 30 Oktober 2019 \\ in revised form: 14 Januari \\ Accepted: 16 Februari 2020 \\ Available Online: 02 Maret 2020 \\ Keywords: \\ Arumanis mango leaves \\ Mangifera indica $\mathrm{L}$. \\ Purified extract \\ Escherichia coli \\ Staphylococcus aureus \\ Thin Layer Chromatography \\ Corresponding Author: \\ Dewi Andini Kunti Mulangsri \\ Fakultas Farmasi \\ Universitas Wahid Hasyim \\ 50232 \\ Semarang \\ Indonesia \\ email: andini@unwahas.ac.id
}

Dewi Andini Kunti Mulangsri ${ }^{1 *}$, Elya Zulfa ${ }^{1}$

I*Jurusan Farmasi, Fakultas Farmasi, Universitas Wahid Hasyim, Semarang, Indonesia.

\begin{abstract}
Arumanis mango leaves (Mangifera indica L.) has antibacterial activity and antifungal, evidently. E. coli and S. aureus are opportunistic pathogen bacteria that can cause gastrointestinal and skin infection. Purification of extract was done to eliminate the presence of ballast substances that cannot produce therapeutic effects. This study aims to acknowledge the antibacterial activity of purified mango Aumanis leaves extract (PMALE) against $E$. coli and $S$. aureus, flavonoid compound content by TLC. Arumanis mango leaves powder was extracted with $96 \%$ ethanol solvent by maceration method, followed purification the extract was done with hot water-ethylacetate solvent by liquid-liquid extraction method. Antibacterial activity test was done by agar diffusion method against $E$. coli and $S$. aureus bacteria with the same serial concentration of $6.25 ; 12.5 ; 25 ; 50 ; 75$ and $100 \%$ and Thin Layer Chromatography (TLC) tests for detection flavonoid compounds, the stationary phase used silica gel 60F 254 and the mobile phase used n-hexane-ethylacetate (1:3). The results of PMALE had antibacterial activity at lower concentrations as $6,25 \%$ against both of $E$. coli and $S$. aureus. PMALE had flavonoid compounds with Rf values of 0.81 .
\end{abstract}

Copyright $@ 2019$ JFG-UNTAD This open access article is distributed under a Creative Commons Attribution (CC-BY-NC-SA) 4.0 International license.

How to cite (APA $6^{\text {th }}$ Style):

Mulangsri, D. A. K., \& Zulfa, E. (2020). Uji Aktivitas Antibakteri Ekstrak Terpurifikasi Daun Mangga Arumanis (Mangifera indica L.) dan Identifikasi Flavonoid Dengan KLT. Jurnal Farmasi Galenika: Galenika Journal of Pharmacy (e-Journal), 6(1), 55-62. doi:10.22487/j24428744.2020.v6.i1.14044 


\section{ABSTRAK}

Daun mangga arumanis (Mangifera indica L.) telah terbukti memiliki aktivitas antibakteri dan antijamur. E. coli dan $S$. aureus merupakan jenis bakteri patogen opportunistik yang dapat menyebabkan penyakit infeksi di saluran cerna dan kulit. Purifikasi ekstrak dilakukan untuk menghilangkan adanya zat ballast yang tidak dapat menghasilkan efek terapi. Penelitian ini bertujuan untuk mengetahui aktivitas antibakteri ekstrak terpurifikasi daun mangga arumanis (ETDMA) terhadap E. coli dan S. aureus serta kandungan senyawa flavonoid dengan KLT. Serbuk daun mangga arumanis diekstraksi menggunakan pelarut etanol $96 \%$ dengan metode maserasi, dilanjutkan purifikasi ekstrak menggunakan pelarut air panas-etilasetat dengan metode ekstraksi cair-cair. Uji aktivitas antibakteri dilakukan dengan metode difusi agar terhadap kedua bakteri uji dengan seri konsentrasi yang sama yaitu 6,$25 ; 12,5 ; 25 ; 50 ; 75$ dan $100 \%$. Uji Kromatografi Lapis Tipis (KLT) untuk mendeteksi senyawa flavonoid, fase diam silica gel 60F 254, fase gerak $n$-heksan-etilasetat (1:3). Hasil penelitian ETDMA memiliki aktivitas antibakteri pada konsentrasi terkecil yaitu 6,25\% baik terhadap bakteri E. coli dan S. aureus. ETDMA memiliki kandungan senyawa flavonoid dengan nilai Rf 0,81.

Kata kunci: Daun mangga arumanis; Mangifera indica L; ekstrak terpurifikasi; Escherichia coli; Staphylococcus aureus, kromatografi lapis tipis.

\section{PENDAHULUAN}

Tanaman mangga arumanis (Mangifera indica L.) memiliki kandungan senyawa fenol, selain itu terkandung senyawa alkaloid, tannin, terpenoid, antrakuinon, asam amino, flavonoid, saponin, kardiak glikosida dan resin (Diso et al., 2017; Ningsih et al., 2017) serta klorofil (Sumenda et al., 2011). Beberapa senyawa tersebut yang terkandung di dalam tanaman mangga arumanis memiliki aktivitas antimikroba terhadap bakteri Methicillin-Resistant Staphylococcus aureus (Diso et al., 2017), Propionibacterium acnes (Munawwarah et al., 2017) dan Candida albicans (Ningsih et al., 2017). Penelitian sebelumnya telah membuktikan bahwa daun muda dari mangga arumanis terbukti memiliki aktivitas antibakteri terhadap S. mutans (Kurniasih, 2016). Namun pada penelitian ini akan menggunakan daun tua dari mangga arumanis. Daun tua kersen (Muntingia calbura L.) memiliki aktivitas antibakteri lebih besar terhadap bakteri E. coli dan $S$. aureus dikarenakan kandungan flavonoid lebih tinggi dibandingkan daun mudanya (Pujianingsih et al., 2018). Selain dikarenakan kandungan flavonoid lebih tinggi, daun tua ketersediaannya cukup melimpah.

Suatu tanaman dapat menghasilkan suatu komponen senyawa yang memiliki efek terapi dan tidak. Senyawa yang tidak memiliki efek terapi berupa zat ballast seperti karbohidrat, lemak, protein, resin dan klorofil (Balai Penelitian dan Pengembangan Pasca Panen Pertanian). Dengan melakukan purifikasi ekstrak akan menyari komponen senyawa yang memiliki efek terapi saja dan meminimalkan zat ballast ikut tersari. Daun mangga Arumanis mengandung zat ballast seperti resin dan klorofil, sehingga perlu dilakukan purifikasi ekstrak. Pada penelitian sebelumnya, purifikasi ekstrak dari bee propolis bertujuan untuk mendapatkan kandungan flavonoid lebih besar dan murni (Puspitasari \& Pramono 2015), sehingga dengan purifikasi ekstrak dari daun mangga Arumanis juga dapat diperoleh kandungan flavonoid yang lebih besar dan murni. Kadar flavonoid yang lebih besar ternyata dapat mempengaruhi aktivitas antibakteri sebesar 93\% dengan analisis korelasi Pearson antara ekstrak etanol dan fraksi-fraksi daun Kersen (Muntingia calabura L.) (Manik et al., 2014). Jadi besarnya kandungan flavonoid dalam sampel dapat menghasilkan aktivitas yang besar pula. Berdasarkan latar belakang tersebut maka perlu dilakukan uji aktivitas antibakteri ekstrak terpurifikasi daun mangga arumanis (ETDMA) terhadap E. coli dan S. aureus. 


\section{METODE PENELITIAN}

\section{Alat dan Bahan}

Alat-alat yang digunakan dalam penelitian, seperti : oven simplisia, alat penyerbuk elektrik, seperangkat alat maserasi, rotary evaporator (Heidolph), corong pisah (Pyrex), kompor listrik, bejana KLT, cawan petri, glassware, autoclave (All american), Laminar Air Flow, kawat ose. Bahan yang digunakan dalam penelitian, seperti: Etanol $96 \%$ teknis, aquadest, etil asetat teknis, etil asetat pa, $n$ heksan, Escherichia coli ATCC 25922, Staphylococcus aureus ATCC 25923, antibiotik kloramfenikol disk, media Nutrient Agar dan Nutrient Broth (MERCK ${ }^{\circledR}$ ), kapas steril, kertas label.

\section{Metode}

\section{A. Pembuatan Ekstrak Terpurifikasi Daun Mangga Arumanis (ETDMA)}

Daun mangga arumanis setelah disortasi basah dan dipotong tangkainya kemudian dicuci dengan air. Daun mangga arumanis yang telah ditiriskan kemudian dikeringkan dengan oven pada suhu $50^{\circ} \mathrm{C}$. Simplisia Daun mangga arumanis kemudian diserbuk. Sebanyak 1400 gram serbuk simplisia daun mangga arumanis digunakan untuk membuat ekstrak. Pembuatan ekstrak etanol daun mangga arumanis dilakukan dengan metode maserasi dengan pelarut etanol 96\% dengan perbandingan serbuk daun mangga arumanis dan pelarut etanol 96\% adalah 1:10. Maserasi dilakukan selama 3 hari dan remaserasi selama 2 hari. Maserat dipekatkan dengan rotary evaporator pada suhu $50^{\circ} \mathrm{C}$ hingga diperoleh ekstrak kental.

Ekstrak etanol daun mangga arumanis (EEDMA) yang digunakan untuk purifikasi sebanyak 235 gram. EEDMA disuspensikan dengan air panas, kemudian di masukkan ke dalam corong pisah. Pelarut etilasetat ditambahkan ke dalam corong pisah kemudian digojog sampai terjadi 2 lapisan. Lapisan etilasetat dipisahkan dan lapisan air difraksinasi lagi dengan pelarut etilasetat sampai pelarut etilasetat tetap jernih. Lapisan etilasetat yang telah dipisahkan kemudian dikentalkan dengan rotary evaporator pada suhu $50^{\circ} \mathrm{C}$. Fraksi etilasetat inilah yang merupakan ekstrak terpurifikasi daun mangga arumanis.

\section{B. Uji Aktivitas Antibakteri Ekstrak Terpurifikasi Daun Mangga Arumanis (ETDMA)}

Pengujian aktivitas antibakteri dengan metode difusi agar dimulai dengan menyiapkan media Nutrient Broth untuk suspensi bakteri dan Nutrient Agar (NA) untuk media uji. Paperdisk diletakkan di atas permukaan media NA yang telah mengandung suspensi bakteri secara aseptis, kemudian diteteskan larutan ETDMA sebanyak $10 \mu \mathrm{L}$. Konsentrasi larutan ETDMA yang digunakan adalah 6,$25 ; 12,5 ; 25$; 50; 75 dan $100 \%$. Kontrol positif yang digunakan adalah larutan antibiotik Kloramfenikol 30 $\mathrm{\mu g} / \mathrm{disk}$ dan kontrol negatif yang digunakan adalah larutan DMSO sebagai pelarut ekstrak. Inkubasi dilakukan pada suhu $37^{\circ} \mathrm{C}$ selama 24 jam. Diameter Daerah Hambat (DDH) diukur berdasarkan jari-jari penghambatan berupa area bening di sekeliling paperdisk menggunakan jangka sorong.

\section{Uji Kromatografi Lapis Tipis (KLT)}

Uji pendahuluan kandungan senyawa kimia dilakukan sebelum uji KLT dengan pereaksi spesifik. Uji flavonoid menggunakan peraksi $\mathrm{Mg}-\mathrm{HCl}$. Uji KLT untuk senyawa flavonoid menggunakan fase diam lempeng Silica gel ${ }_{60} \mathrm{~F}_{254}$ dan fase gerak terdiri dari campuran $n$-heksan : etilasetat (1:3) (Haeria et al., 2013). Standar pembanding yang digunakan adalah kuersetin. Penampak bercak yang digunakan adalah uap ammonia. Pengamatan dilakukan pada sinar tampak, sinar UV 254 dan UV 365 (Depkes RI, 2000). 


\section{Analisa Data}

Analisis data dilakukan secara deskriptif baik hasil uji aktivitas antibakteri dan uji KLT. Hasil uji aktivitas antibakteri berupa ada tidaknya zona hambat yang terbentuk di sekeliling paperdisk. Zona hambat yang terbentuk diukur DDH dengan jangka sorong. Hasil uji pendahuluan adanya senyawa flavonoid dengan pereaksi $\mathrm{Mg}-\mathrm{HCl}$ akan terbentuk warna merah. Hasil uji KLT dengan penampak bercak uap ammonia akan terbentuk warna kuning intensif yang nampak pada sinar tampak, pada UV $254 \mathrm{~nm}$ terbentuk bercak gelap dan UV $366 \mathrm{~nm}$ terbentuk warna kuning gelap, hijau atau biru berfluoresensi (Markham, 1975).

\section{HASIL DAN PEMBAHASAN}

Ekstrak etanol daun mangga arumanis yang diperoleh sebesar 273,5 gram dengan rendemen ekstrak 19,54\%; sedangkan ETDMA diperoleh 50,7 gram dari 235 gram EEDMA dengan rendemen 21,57\%. ETDMA yang diperoleh memiliki warna hijau kecoklatan, sedangkan EEDMA memiliki warna hijau pekat. ETDMA ini pada pengujian aktivitas antibakteri memberikan hasil bahwa ETDMA memiliki aktivitas antibakteri terhadap bakteri $E$. coli dan $S$. aureus. Adanya aktivitas antibakteri pada bakteri uji adalah terbentuknya zona hambat di sekitar paperdisk mulai konsentrasi 6,25\% sudah menghasilkan zona hambat pada kedua bakteri uji. Zona hambat yang terbentuk dilakukan pengukuran DDH-nya. Diameter daerah hambat yang telah diukur disajikan dalam Tabel I dan II. Pada larutan ETDMA konsentrasi 25-100\% cukup kental, hal ini mengakibatkan absorbsi larutan ETDMA ke dalam paperdisk tidak maksimal dan nampak meluber di sekitar paperdisk. Penggunaan konsentrasi untuk uji aktivitas antibakteri ETDMA akan lebih baik di bawah konsentrasi 25\%. Pada konsentrasi 6,25\% dan 12,5\% larutan ETDMA tidak terlalu kental sehingga dapat terabsorbsi maksimal ke dalam paperdisk dan tidak meluber di sekitar paperdisk. Sehingga dapat disampaikan bahwa ETDMA memiliki aktivitas antibakteri pada konsentrasi terkecil 6,25\% terhadap bakteri E. coli dan $S$. aureus. Sedangkan ekstrak daun manga arumanis (Mangifera indica L.) pada konsentrasi $100 \%$ telah terbukti memiliki aktivitas antibakteri terhadap E. coli (DDH 14,6667 mm) dan S. aureus (DDH 16,6667 mm) (Purwanti et al., 2014) yang mana konsentrasi 100\% masih lebih besar daripada ETDMA untuk memperoleh nilai DDH tersebut, sehingga ETDMA memiliki potensi lebih besar dibandingkan EEDMA. Uji aktivitas antibakteri ETDMA terhadap kedua bakteri uji dapat dilihat pada Gambar 1.

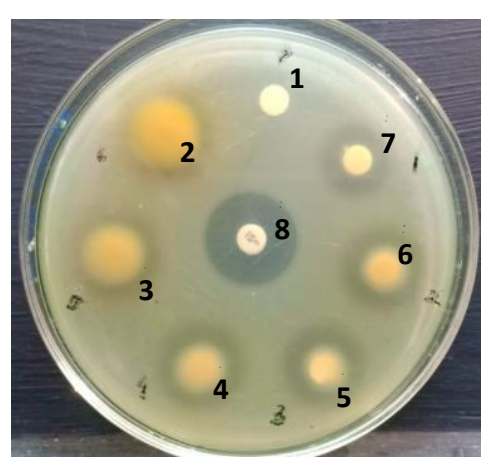

A

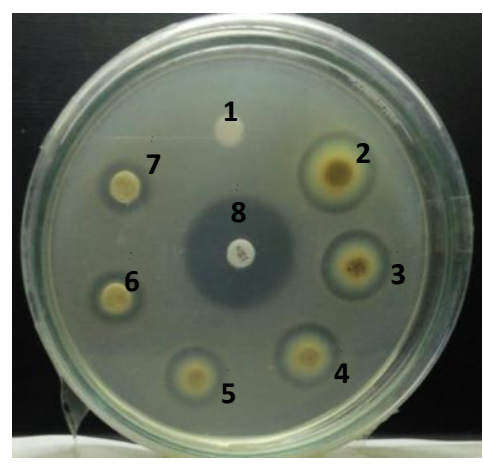

B

Keterangan :

1. kontrol negatif DMSO

2. konsentrasi $100 \%$

3. konsentrasi $75 \%$

4. konsentrasi $50 \%$
5. konsentrasi $25 \%$

6. konsentrasi $12,5 \%$

7. konsentrasi $6,25 \%$

8. kontrol positif, Kloramfenikol 30 g/disk

Gambar 1. Hasil uji aktivitas antibakteri ETDMA terhadap E. coli (A) dan S. aureus (B), Ø paperdisk: $6 \mathrm{~mm}$ 
Tabel I. Nilai DDH pada bakteri E. coli

\begin{tabular}{ccccc}
\hline Sampel & \multicolumn{3}{c}{ Diameter Daerah Hambat } & Rata-rata \pm SD \\
& & \multicolumn{3}{c}{} \\
\cline { 2 - 4 } & I & II & III & \\
\hline $6,25 \%$ & 15,03 & 16,52 & 15,52 & $15,69 \pm 0,76$ \\
\hline $12,5 \%$ & 16,64 & 16,84 & 17,54 & $17,00 \pm 0,47$ \\
\hline $25 \%$ & 17,60 & 17,52 & 18,34 & $17,82 \pm 0,45$ \\
\hline $50 \%$ & 19,07 & 18,20 & 18.76 & $18,68 \pm 0,41$ \\
\hline $75 \%$ & 19,65 & 20,52 & 20,55 & $20,24 \pm 0,51$ \\
\hline $100 \%$ & 23,40 & 22,06 & 21,89 & $22,45 \pm 0,18$ \\
\hline Kloramfenikol & 24,18 & 24,10 & 24,18 & $24,15 \pm 0,05$ \\
\hline DMSO & - & - & - & - \\
\hline
\end{tabular}

Tabel II. Nilai DDH pada bakteri S. aureus

\begin{tabular}{ccccc}
\hline \multirow{2}{*}{ Sampel } & \multicolumn{3}{c}{ Diameter Daerah Hambat } \\
& & $(\mathrm{mm})$ & \multirow{2}{*}{ Rata-rata \pm SD } \\
& I & II & III & \\
\cline { 2 - 4 } $6,25 \%$ & 14,02 & 12,50 & 13,02 & $13,18 \pm 1,31$ \\
\hline $12,5 \%$ & 15,04 & 15,52 & 14,54 & $15,03 \pm 1,33$ \\
\hline $25 \%$ & 15,52 & 16,64 & 15,52 & $15,89 \pm 0,65$ \\
\hline $50 \%$ & 16,19 & 16,77 & 14,51 & $15,82 \pm 1,17$ \\
\hline $75 \%$ & 17,54 & 17,44 & 17,55 & $17,51 \pm 0,06$ \\
\hline $100 \%$ & 21,26 & 18,90 & 19,64 & $19,93 \pm 1,32$ \\
\hline Kloramfenikol & 27,11 & 26,28 & 27,05 & $26,81 \pm 1,51$ \\
\hline DMSO & - & - & - & - \\
\hline
\end{tabular}

Hasil uji aktivitas antibakteri ETDMA menunjukkan bahwa ETDMA berpotensi terhadap bakteri yang bertipe dinding sel Gram negatif dan Gram positif. Bakteri Gram negatif (E. coli) memiliki lapisan paling luar dari dinding selnya yang mengandung lipopolisakarida dengan kandungan lipid A bersifat hidrofobik (Raetz \& Whitfield, 2002). Sedangkan dinding sel bakteri Gram positif (S. aureus) mengandung peptidoglikan yang tebal yang terdiri dari pengulangan disakarida yang melekat pada jembatan peptide (Pratiwi, 2008). 
Pelarut etanol $96 \%$ akan menyari senyawa-senyawa seperti tannin, polifenol, poliacetilen, flavonol, terpenoid, steroid, alkaloid dan saponin (Tiwari et al., 2011; Rahman et al., 2017 dan Nirwana et al., 2015). Ekstrak etanol daun mangga arumanis (EEDMA) dilakukan uji skrining fitokimia juga dan hasilnya positif mengandung flavonoid, tannin dan saponin. Senyawa yang tersari dalam air panas berupa karbohidrat, protein dan asam amino, fitosterol, flavonoid, saponin, terpenoid, steroid, tanin dan alkaloid (Itoandon et al., 2012). Pelarut air sendiri merupakan pelarut universal, sehingga dapat menyari senyawa dengan kepolaran nonpolar sampai polar (Tiwari et al., 2011). Namun air panas yang digunakan ini dalam proses penyarian bertujuan untuk tidak mengikutkan zat ballast yang bersifat nonpolar (Puspitasari \& Pramono, 2015). Hasil uji skrining fitokimia ETDMA positif hanya mengandung flavonoid dan tanin. Purifikasi ekstrak dengan pelarut air panas dan etilasetat akan menghasilkan kadar flavonoid lebih tinggi dan murni dibandingkan dengan pelarut etanol $30 \%$ dan kloroform (Puspitasari \& Pramono, 2015). Oleh sebab itu penelitian ini menggunakan dua pelarut yaitu air panas dan etilasetat dalam proses purifikasi ekstrak agar diperoleh kadar flavonoid lebih tinggi dan murni. Senyawa flavonoid berperan banyak terhadap aktivitas farmokologi, salah satunya antibakteri.

Uji KLT digunakan untuk mempertegas adanya senyawa flavonoid dari hasil uji fitokimia. Hasil uji KLT senyawa flavonoid pada sampel ETDMA (2) dengan nilai Rf 0,81 sedangkan nilai Rf Kuersetin (3) adalah 0,85. Nilai Rf EEDMA tidak dilakukan pengukuran dikarenakan lebih fokus pada kandungan flavonoid pada ETDMA yang ingin dibandingkan karakteristiknya dengan kuersetin (baku pembanding flavonoid). Setelah diuapi ammonia pada sinar tampak, kuersetin nampak menjadi kuning, namun sampel ETDMA dan EEDMA nampak sedikit berwarna kuning. Pada pengamatan sinar UV $254 \mathrm{~nm}$, kuersetin menjadi gelap begitu juga pada spot ETDMA dan EEDMA. Pada pengamatan sinar UV $366 \mathrm{~nm}$, kuersetin nampak berfluoresensi kuning, begitu juga dengan ETDMA, namun pada sampel EEDMA belum nampak begitu jelas. Nilai Rf ETDMA yang mendekati nilai Rf Kuersetin dan warna bercak yang mirip dengan kuersetin dapat ditegaskan bahwa senyawa flavonoid tersebut adalah senyawa flavonoid kuersetin atau memiliki karakteristik seperti kuersetin. Hasil uji KLT senyawa flavonoid ditunjukkan pada Gambar 2.

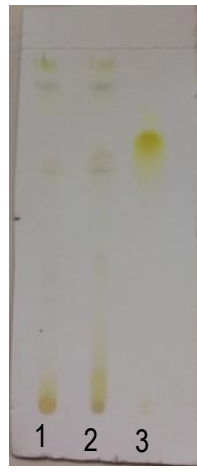

A

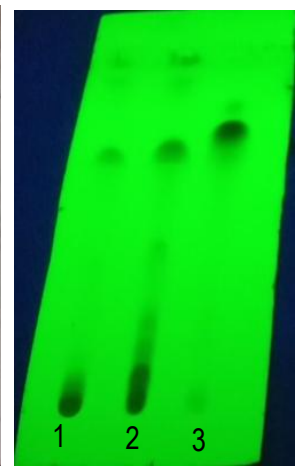

B

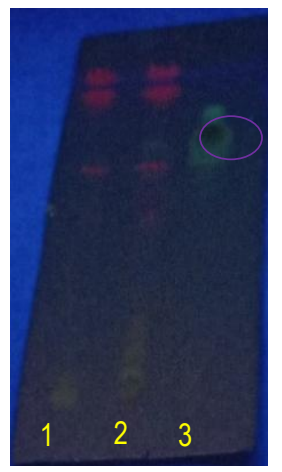

C

Keterangan :

$\begin{array}{llll}1 & \text { : EEDMA } & \text { A } & \text { : diamati di sinar tampak } \\ 2 & : \text { ETDMA } & \text { B } & \text { : diamati di sinar UV 254nm } \\ 3 & : \text { standar Kuersetin } & \text { C } & \text { : diamati di sinar UV 366nm }\end{array}$

Gambar 2. Hasil Uji Klt Senyawa Flavonoid

\section{KESIMPULAN}

Ekstrak terpurifikasi daun mangga arumanis memiliki aktivitas antibakteri terhadap bakteri Gram negatif $E$. coli dan Gram positif $S$. aureus serta hasil uji KLT terdeteksi senyawa flavonoid. 


\section{UCAPAN TERIMAKASIH}

Ucapan terimakasih ditujukan kepada Kemenristekditi yang telah memberikan bantuan dana penelitian berupa Penelitian Dosen Pemula (PDP) sehingga penelitian ini dapat terlaksana.

\section{DAFTAR PUSTAKA}

Balai Besar Penelitian Dan Pengembangan Pascapanen Pertanian. Tanaman Obat.Teknologi Pascapanen Tanaman Obat. Bogor.

Depkes RI. (2000). Parameter Standar Umum Ekstrak Tumbuhan Obat. Jakarta: Dirjen POM.

Diso, S U., Ali, M., Mukhtar, S I., \& Garba, M. (2017). Antibacterial Activity and Phytochemical Screening of Mangifera indica (Mango) Stem and Leaf Extracts on Clinical Isolates of Methicillin Resistant Staphylococcus aureus. Journal of Advances in Medical and Pharmaceutical Sciences, 13 (1): 1-6.

Haeria. (2013). Penetapan Kadar Flavonoid Total dan Uji Daya Antioksidan Ekstrak Etanol Daun Ungu (Graptophyllum pictum L.) Griff). JF FIK UINAM. 1(1): 3

Itoandon, E. E., Olatope, S. O. A., \& Shobowale, O. O. (2012). Preliminary Phytochemical Analysis and Antimicrobial Properties of Crude Extract of Combretodendron macrocarpum Stem Bark. Nigerian Food Journal. 30(2): 53.

Kurniasih, R. (2016). Pengaruh Konsentrasi Ekstrak Etanol Daun Mangga Arumanis Muda (Mangifera indica L.) Terhadap Hambatan Pertumbuhan Bakteri Streptococcus mutans, Skripsi, Universitas Muhammadiyah Surakarta.

Manik, D. E., Hertiani, T. \& Anshory, H. (2014). Analisis Korelasi Antara Kadar Flavonoid Dengan Aktivitas Antibakteri Ekstrak Etanol Dan Fraksi-Fraksi Daun Kersen (Muntingia calabura L.) Terhadap Staphylococcus aureus. Khazanah. 6(2): 1.

Markham, K. (1975). Isolation Technique for Flavonoid, dalam The Flavonoid, Harborne, J.B., Mabry, T.J., dan Mabry, H. Academic Press: New York.

Munawwarah, Z. F., Aufia, W., \& Masitha, N. (2017). Uji Aktivitas Antibakteri Ekstrak Etanol Biji Mangga (Mangifera indica L.) Terhadap Propionibacterium acnes. Pharmasipha,1(1).

Ningsih D. R., Zusfahair \& Mantari D. (2017). Ekstrak Daun Mangga (Mangifera indica L.) Sebagai Antijamur Terhadap Jamur Candida albicans Dan Identifikasi Golongan Senyawanya. Jurnal Kimia Riset. 2 (1): 61-68.

Nirwana, A. P., Astirin, O. P., \& Widyani, T. (2015). Skrining Fitokimia Ekstrak Etanol Daun Benalu Kersen (Dendrophtoe pentandra L. Miq). EL-VIVO.3(2): 9.

Pratiwi, S. T. (2008). Mikrobiologi Farmasi. Jakarta: Erlangga.

Pujianingsih R.I. Sulistyanto B. \& Sumarsih S. (2018). Observation of Muntingia calabura's Leaf Extract as Feed Additive for Livestock Diet. IOP Conference Series : Earth and Enviromental Science.

Purwanti, E., Handijatno, D., Yunus, M. (2014). Efek Antibakteri Ekstrak Daun Mangga (Mangifera Indica) Terhadap Staphylococcus aureus dan Escherichia coli. Veterinaria Medik. 7(3): 266271 
Puspitasari A. D. \& Pramono S. (2015). Perbandingan Metode Pembuatan Ekstrak Terpurifikasi Bee Propolis Dari Lebah Madu (Apis mellifera) Berdasarkan Kadar Flavonoid Total Dihitung Sevagai Rutin, Trad. Med. J., 20(2): 76-81.

Raetz, C. R. H. \& Whitfield, C. (2002). Lipopolysaccharide Endotoxin. Annu Rev Biochem. 71: 1.

Rahman, F. A., Haniastuti, T. \& Utami, T. W. (2017). Skrining Fitokimia dan Aktivitas Antibakteri Ekstrak Etanol Daun Sirsak (Annona muricata L.) pada Streptocccus mutans ATCC 35668. Majalah Kedokteran Gigi Indonesia. 3(1): 1.

Sumenda, L., Rampe, H. L., \& Mantiri, F R. (2011). Analisis Kandungan Klorofil Daun Mangga (Mangifera indica L.) pada Tingkat Perkembangan Daun Yang Berbeda, 1-5.

Tiwari, P., Kumar, B., Kaur, M., Kaur, G. \& Kaur, H. (2011). Phytochemical Screening and Extraction: A Review. International Pharmaceutica Sciencia, 1(1): 101. 